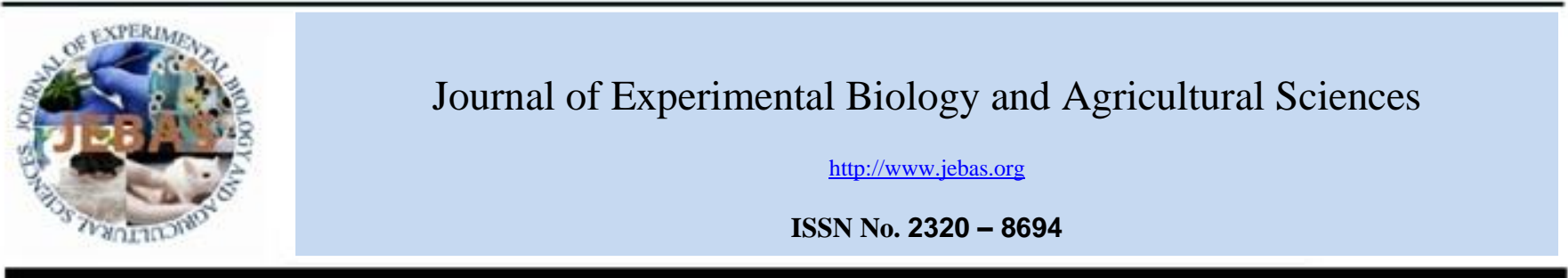

\title{
BIOAVAILABLE FORMS OF HEAVY METALS FROM RICE SAMPLES AND ITS POTENTIAL HEALTH RISK ASSESSMENT
}

\section{Periyasamy Dhevagi ${ }^{1 *}$, Ambikapathi Ramya ${ }^{1}$, Sengottiyan Priyatharshini ${ }^{2}$, Murugaiyan Sindhuja $^{1}$, Subramanian Avudainayagam ${ }^{3}$}

\footnotetext{
${ }^{1}$ Department of Environmental Sciences, Tamil Nadu Agricultural University, Coimbatore, Tamil Nadu, 641003, India

${ }^{2}$ Department of Crop Management, Vanavarayar Institute of Agriculture, Pollachi, Tamil Nadu, 642103, India

${ }^{3}$ Principal, Dhanalakshmi Srinivasan Agriculture College, Thuraiyur Road, Permbalur -621212
}

Received - October 09, 2020; Revision - January 04, 2021; Accepted - February 10, 2021

Available Online - February 27, 2021

DOI: http://dx.doi.org/10.18006/2021.9(1).25.35

\section{KEYWORDS \\ Polished rice \\ Heavy metals \\ Bioaccessibility \\ Total hazard quotient}

\begin{abstract}
Food crops grown in contaminated soils have a greater accumulation of heavy metals and the consumption of food crops grown in the contaminated soils are the source of metals that enters into the human body. Rice being a major food crop, the presence of heavy metals should be monitored regularly for reducing health risk. The analysis of total heavy metal always overestimates the content which leads to misinterpretation of results; however, bioaccessible heavy metal analysis projects the actual health risk. Hence, the present study aims to assess the bioavailable form of heavy metals in rice. The rice samples were collected from 20 different places and used for the inherent and bioavailable metal estimation. In vitro simulated digestion method was applied for bioaccessible metal analysis. Metal concentration in polished rice ranged from 0.10 to $0.82,0.10$ to $1.07,0.11$ to 0.56 and 0.23 to $1.09 \mathrm{mg} \mathrm{kg}^{-1}$ for Lead ( $\mathrm{Pb})$, Nickel (Ni), Cadmium (Cd) and Chromium (Cr), respectively. Twenty five percent of the samples recorded less than $0.028,0.01,0.01$, and $0.03 \mathrm{mg} \mathrm{kg}^{-1}$ of bioaccessible $\mathrm{Pb}, \mathrm{Ni}, \mathrm{Cd}$, and $\mathrm{Cr}$, respectively. A significant negative correlation was observed between total metal concentration and bioaccessibility percentage. Targeted Hazard Quotient (THQ) of all the metals were less than one for adults indicating that there were no health risks, which undoubtedly reveals the importance of bioaccessible metal analysis. Hence, regular monitoring of heavy metals is essential to reduce the intensive accumulation in the human food chain. Also, the present study has opened up a wide scope on human health risk assessment using an in vitro digestion model.
\end{abstract}

* Corresponding author

E-mail: devagisivaraj@gmail.com (Periyasamy Dhevagi)

Peer review under responsibility of Journal of Experimental Biology and Agricultural Sciences.

Production and Hosting by Horizon Publisher India [HPI] (http://www.horizonpublisherindia.in/).

All rights reserved.
All the articles published by Journal of Experimental Biology and Agricultural Sciences are licensed under a Creative Commons Attribution-NonCommercial 4.0 International License Based on a work at www.jebas.org.

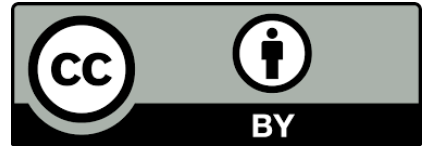




\section{Introduction}

Heavy metals are the major contaminants causing serious health risks. There are many sources through which heavy metals are entering the human body and dietary accumulation via food crops often been reported by many researchers (Chaoua et al., 2019; Ghuniem et al., 2020). Investigation of metal accumulation in food grains is crucial, especially in rice. Since, rice can absorb metals from the soil than any other crops (Khairiah et al., 2013) due to its prevailing anaerobic conditions which favors the metals mobilization from roots to economic part (Huang et al., 2016).

The most preferable form by the people and easily available in the market is polished rice. for consumption which also contains heavy metals. Naseri et al. (2018) reported Ni concentrations of $0.49 \pm 0.51 \mu \mathrm{g} \mathrm{g}^{-1}$ in the polished rice. Sen Gupta et al. (2016) observed polished Tamil Nadu Ponni rice, Karnataka Ponni, IR 20, Basmati rice, and reported purchased from the market showed 324.6, 245.3, 243.0, $309.5 \mathrm{ppm}$ of $\mathrm{Cr}$ respectively. Similarly, many researchers reported on the presence of heavy metals in rice. Unlike raw rice, polished rice, polished rice is milled to remove the husk, bran, germ, and nutrients to some extent while processing, many researchers observed the presence of metals in the polished rice (Jorhem et al., 2008; Hang et al., 2009; Bhattacharya et al., 2010; Ihedioha et al., 2016; Cao et al., 2017).

The major drawback associated with total heavy metal estimation is an overestimation of the bioconcentration factor that leads to misinterpretation of actual human health risks. To fulfill the above lacuna, in vitro simulation studies used which estimates the fraction of metals that are available for absorption in the human gastrointestinal environment. The reliability of such studies was evident based on In vivo-in vitro correlation studies done by Juhasz et al. (2006) who confirmed the validity of in vitro methods for predicting relative bioavailability (RBA) of metals (arsenic and mercury) in foods. The validity of in vitro simulation of the human digestive tract including the stomach and small intestine were also confirmed by many researchers (Ruby et al., 1996; Sandberg, 2005; Intawongse \& Dean, 2008; Sun et al., 2012).

The risk evaluation study carried out from marketed consumable rice samples would depict precise results compared to rice obtained from the field (Devesa et al., 2008). Chandorkar \& Deota (2013) investigated the bioavailability of heavy metals in rice varieties available in the local supermarket. As apparent from number of previous studies, it is clear that in rice grain, total heavy metal content was explored rather than a bioaccessible fraction. Kumari \& Kalpana (2017) studied human health risk assessment by focusing on bioaccessible heavy metals in cereals. However the studies on the bioaccessible form of heavy metal are very limited, the present investigation was carried out to give a clear view of exposure risks to humans by determining the bioaccessible heavy metals in rice.

\section{Materials and methods}

Twenty rice samples (20 nos) were randomly purchased from local consumer superstores in and around Thondamuthur, Coimbatore (Table 1).

Table 1 Rice samples collected locations around Thondamuthur,

\begin{tabular}{|c|c|}
\hline Sample no. & Name of the Place \\
\hline S1 & Perur Chettipalayam \\
\hline S2 & Pachapalayam \\
\hline S3 & Theetheepalayam \\
\hline S4 & Kalampalayam \\
\hline S5 & Madampatti \\
\hline S6 & Kuppanur \\
\hline S7 & Thenkarai \\
\hline S8 & Chennanur Thenkarai \\
\hline S9 & Ikkarai Poluvampatti \\
\hline S10 & Nathegoundenpalayam \\
\hline S11 & Alandurai \\
\hline S12 & Madwarayapuram \\
\hline S13 & Booluvampatti \\
\hline S14 & Jahirnaickenpalayam \\
\hline S15 & Narashipuram \\
\hline S16 & Vellimalaipattinam \\
\hline S17 & Pullagoundenpalayam \\
\hline S18 & Devarayapuram \\
\hline S19 & Parameswaranpalayam \\
\hline S20 & Thennamanallur \\
\hline
\end{tabular}

Tamil Nadu Pooni was chosen for the study based on consumer preference and the origin of the rice samples were taken from the package label. Among the samples, 35\% were from Villupuram origin. A total of $50 \mathrm{~g}$ of polished rice from each sample was weighed and washed three times with deionized water, then cooked with $100 \mathrm{ml}$ of deionized (1:2 ratio) water. The cooked samples were dried, powdered and five gram of powdered samples were taken for analysis. Convenience sampling was chosen as the sampling method for the present study for easy accessibility and availability (Etikan et al., 2016).

Determination of bioaccessible form of heavy metal was done via in vitro digestion using RIVM (Rijksinstituut voor 
Volksgezondheid en Milieu) model (Versantvoort et al., 2005) as it mimics the human physiological condition includes simulated digestive processes starting from the mouth, stomach, and finally to the small intestine (Yang et al., 2012). The chemicals and reagents used for artificial saliva, gastric juice, and duodenal juice were obtained from SIGMA, MERCK, and ACS reagents to minimize the contribution of trace heavy metals from these chemicals. The simulated digestive process was initiated by adding $6.6 \mathrm{ml}$ of artificial saliva to $5 \mathrm{~g}$ of cooked rice sample to represent the digestion process in the mouth. The mixture was then incubated for $5 \mathrm{~min}$, and the $\mathrm{pH}$ was adjusted to 6.8. Afterward, $13.8 \mathrm{ml}$ of artificial gastric juice was added, and the mixture was shaken for $2 \mathrm{~h}$ to represent the digestion process in the stomach. The $\mathrm{pH}$ of the gastric juice was adjusted between 2.0 and 3.0. Finally, $13.8 \mathrm{ml}$ of duodenal juice, $6.7 \mathrm{ml}$ of bile juice, $2.2 \mathrm{ml}$ of $\mathrm{NaHCO}_{3}$ solution $(1 \mathrm{~mol} / \mathrm{L})$ were added simultaneously to represent the digestion process in the small intestine. Subsequently, the mixture was shaken for another $2 \mathrm{~h}$ and the $\mathrm{pH}$ was adjusted from 6.5 to 7.0 and incubated at $37 \pm 2{ }^{\circ} \mathrm{C}$ by using a continuous orbital shaker $(55 \mathrm{rpm})$. In each step of the digestion processes in the mouth, stomach, and small intestine shaking was given for a certain period. The mixture was centrifuged at $2750 \mathrm{rpm}$ for 10 min and the supernatant was collected and filtered through filter paper with a pores size of $0.45 \mu \mathrm{m}$ and used for analysis (Versantvoort et al., 2005; Yang et al., 2012).

The heavy metals, $\mathrm{Pb}, \mathrm{Ni}, \mathrm{Cd}$, and $\mathrm{Cr}$ were estimated using Atomic Absorption Spectrophotometer (Varian AA240). These heavy metals were calibrated by a standard solution using calibration points $(0,2,4,6,8,10 \mathrm{ppm})$ and a linear curve was obtained with an $\mathrm{R}^{2}$ value of 0.9999 (Sunitha et al., 2015). The bioaccessibility percentage was calculated by using the formula of Kumari \& Kalpana, (2017) as mentioned below

$$
\text { Bioaccessibility }(\%)=100 \times \frac{Y}{Z}
$$

Where $\mathrm{Y}$ is the metal content in the bioaccessible fraction ( $\mathrm{mg}$ of metal $/ 100 \mathrm{~g}$ sample) and $\mathrm{Z}$ is the total content of the particular metal (mg of metal/100g sample). Total hazard quotient (THQ) was calculated using the formula given by USEPA (2007).

$$
\mathrm{THQ}=\frac{\mathrm{EF}_{\mathrm{r}} \times \mathrm{ED} \times \mathrm{FI} \times \mathrm{MC} \times 10^{-3}}{\mathrm{R}_{\mathrm{f}} \mathrm{D}_{\mathrm{o}} \times \mathrm{BW} \times \mathrm{AT}}
$$

Where, THQ- Total hazard Quotient; $\mathrm{EF}_{\mathrm{r}}$ - Exposure Frequency (365 days $\mathrm{yr}^{-1}$ ); ED- Exposure Duration - 65 years; FI- Food ingestion per day $\left(0.208 \mathrm{~kg} \mathrm{day}^{-1}\right.$ person $\left.^{-1}\right) ; \mathrm{MC}-$ Metal concentration in food ( $\mathrm{mg} \mathrm{kg}^{-1}$ of $\mathrm{FW}$ basis); BW- Average body weight (53 kg of Indian man); AT- Averaging time for carcinogens; $\mathrm{R}_{\mathrm{f}} \mathrm{D}_{0}$ - Oral reference dose. Oral reference doses were
4E-03, 1E-03, 5E-03 for Pb, Cd, Cr, and Ni, respectively (Dang et al., 1996; USEPA 1997; USEPA 2020).

Pearson correlation analysis was carried out between the total metal content and the bioaccessible percentage. Principle component analysis (PCA) was performed using all observed variables. All the statistical analysis was carried out using SPSS 16 (version 16.0.0). $P$-value less than $0.05(P<0.05)$ is considered as significant. The graphs were plotted using OriginPro 2019 (version 9.6.5).

\section{Results and discussion}

Food crops contaminated with heavy metal via dietary intake undoubtedly are the entry route for human exposure. Among the food crops, rice constitutes more than $90 \%$ of the global cereal production and it supplies nearly half of the daily calories of the world population (Abbas et al., 2011; Ray et al., 2019). Heavy metal elements that commonly found in rice are iron $(\mathrm{Fe})$, zinc $(\mathrm{Zn})$, manganese $(\mathrm{Mn})$, chromium $(\mathrm{Cr})$, cobalt $(\mathrm{Co})$, copper $(\mathrm{Cu})$, arsenic (As), and cadmium (Cd) (Khairiah et al., 2013; Ghuniem et al., 2020). Praveena \& Omar (2017) reported total concentration of $\mathrm{Cr}, \mathrm{Cd}$, and $\mathrm{Pb}$ in rice was $2.7,0.16$, and $0.11 \mathrm{mg} \mathrm{kg}^{-1}$ respectively. The presence of toxic elements in marketed rice is unavoidable due to its ability of accumulation and non-biodegradable nature (Morekian et al., 2013; Huang et al., 2016; Khanam et al., 2020). Several studies in India have reported that a high accumulation of heavy metals was noticed in cereal crops as compared to other crops (Bhattacharya et al., 2010; Singh et al., 2011; Satpathy et al., 2014).

\subsection{Total heavy metals}

In the present study, the inherent lead $(\mathrm{Pb})$ content of the samples varied from 0.10 to $0.82 \mathrm{mg} \mathrm{kg}^{1}$ and $50 \%$ of the samples had a metal concentration above the maximum permissible limit (0.2 $\mathrm{mg} \mathrm{kg}^{-1}$ ) given by WHO (2004). Lead content varied from sample to sample due to many factors and very low lead content ( 0.003 to $0.46 \mathrm{mg} \mathrm{kg}^{-1}$ ) was reported by Singh et al. (2014); whereas Ihedioha et al. (2016) reported $3.99 \pm 1.43 \mathrm{mg} \mathrm{kg}^{-1}$ of $\mathrm{Pb}$ in polished rice.

The studied sample contains Nickel (Ni) in the range of 0.10 to $1.07 \mathrm{mg} \mathrm{kg}^{-1}$ and about half of the samples showed metal content above the permissible limit. Ihedioha et al. (2016) reported a higher level of $\mathrm{Ni}\left(3.12 \pm 1.49 \mathrm{mg} \mathrm{kg}^{-1}\right)$ in raw rice as compared to the present study. Long-term application of wastewater for irrigation has shown to increase heavy metals contamination in cultivated crops which would lead to several health hazards (Rai \& Tripathi 2008). Cadmium (Cd) content varied from 0.11 to 0.56 $\mathrm{mg} \mathrm{kg}^{-1}$ in polished rice and each sample differed significantly from each other and this may be due to the variations in the origin of the 

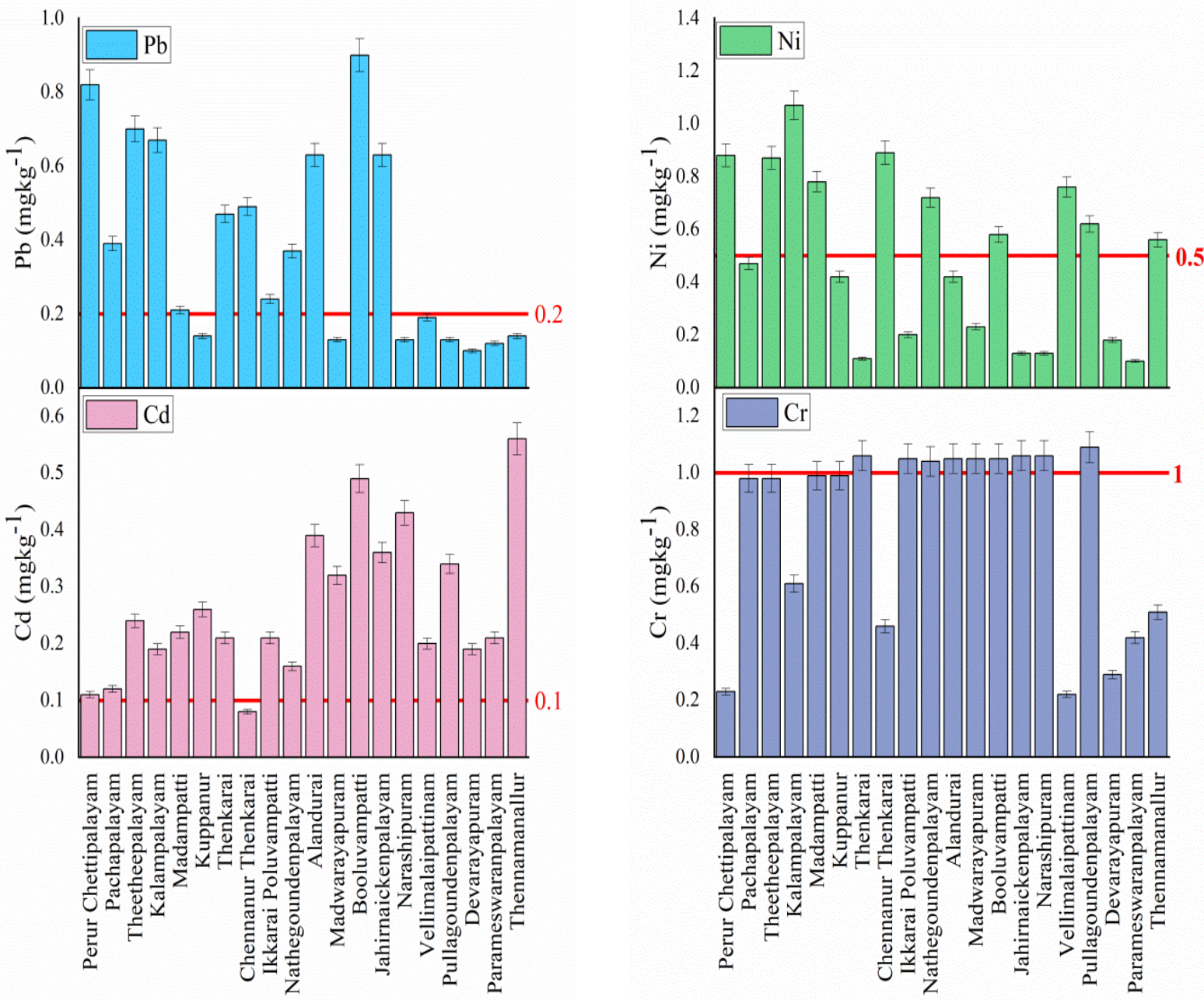

Figure 1 Total metal concentration in rice samples (Straight red line indicates WHO(2004) standards for respective heavy metals)

samples. Chandorkar \& Deota (2013) $\left(1.67 \mathrm{mg} \mathrm{kg}^{-1}\right)$, Singh et al. (2014) $\left(0.25 \mathrm{mg} \mathrm{kg}^{-1}\right)$ and Ihedioha et al. (2016) $(1.10 \pm 0.53$ $\mathrm{mg} \mathrm{kg}^{-1}$ ) also reported $\mathrm{Cd}$ in polished rice.

Chromium (Cr) content varied from 0.23 to $1.09 \mathrm{mg} \mathrm{kg}^{-1}$, in polished rice. Singh et al. (2014) $\left(0.07 \mathrm{mg} \mathrm{kg}^{-1}\right)$ and Solidum et al. (2012) $\left(6.3 \times 10^{-6}\right.$ to $\left.6.5 \times 10^{-6} \mathrm{mg} \mathrm{kg}^{-1}\right)$ also reported $\mathrm{Cr}$ in rice which was quite low when compared to the present study. Omar et al. (2015) reported very low $\mathrm{Cr}$ concentration in cooked rice was $0.13 \mathrm{mg} \mathrm{kg}^{-1}$ unlike in the present study. Sen Gupta et al. (2016) observed $324.6 \mathrm{mg} \mathrm{kg}^{-1}$ of $\mathrm{Cr}$ in Tamil Nadu Ponni rice purchased from the market. Praveena \& Omar (2017) reported total concentration of $\mathrm{Cr}, \mathrm{Cd}$, and $\mathrm{Pb}$ in rice was $2.7,0.16$, and $0.11 \mathrm{mg}$ $\mathrm{kg}^{-1}$, respectively. The total metal content of rice samples was depicted in Figure 1.

\subsection{Bioaccessible heavy metals}

Health risks caused by heavy metal contaminated food materials are well known, however, only a limited extent was used to assess the health risks (Versantvoort et al., 2005). The boxplot of the 20 sampling points with bioaccessible metals were displayed in Figure 2. The $75 \%$ of sampling points recorded the bioaccessible $\mathrm{Pb}, \mathrm{Ni}$, $\mathrm{Cd}$, and $\mathrm{Cr}$ less than 0.088, 0.033, 0.073, and $0.08 \mathrm{mg} \mathrm{kg}^{1}$ respectively. Bioaccessible $\mathrm{Pb}$ in rice ranged between 0.01 to 0.22 $\mathrm{mg} \mathrm{kg}^{-1}$ with the median of $0.05 \mathrm{mg} \mathrm{kg}^{-1}$. Samples showed significant variations in the bioaccessible lead content, which was reflected in the accessible percent (1.43 to 59.46\%). In the present study, there was a reduction in lead content in bioaccessible fraction, when compared to lead content in polished rice (from 0.01 to 0.22 to 0.1 to $0.82 \mathrm{mg} \mathrm{kg}^{-1}$ ). The same observation was 


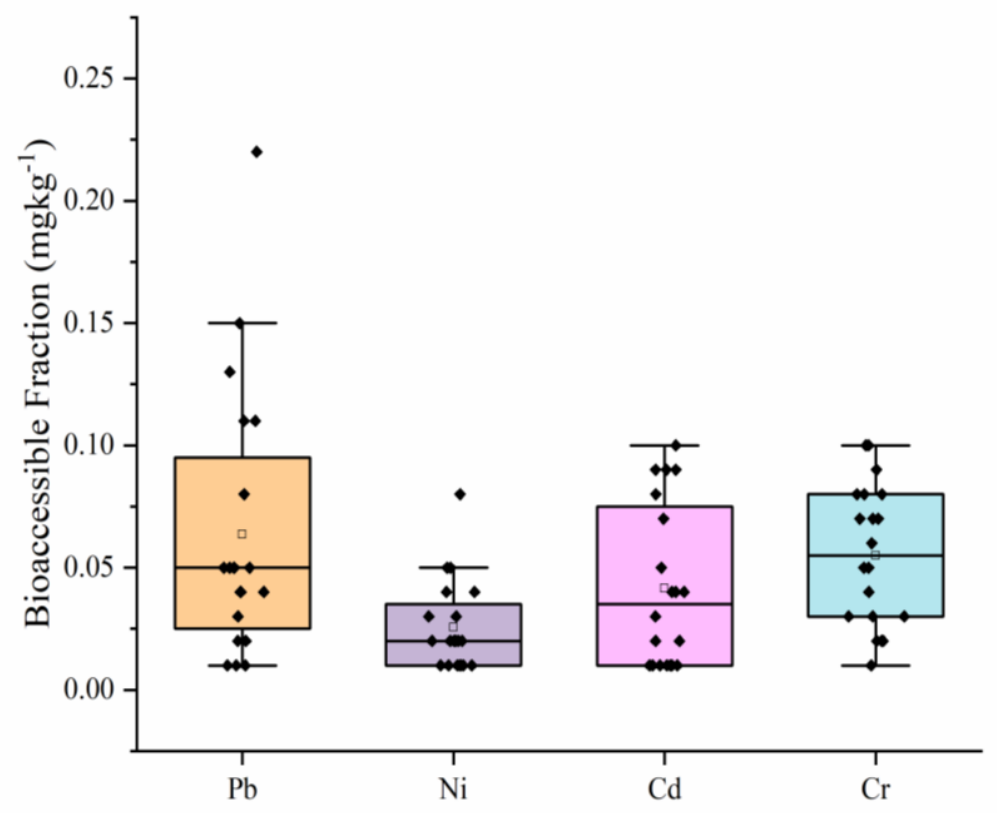

Figure 2 The boxplots of samples representing bioaccessible $\mathrm{Pb}, \mathrm{Ni}, \mathrm{Cd}$ and $\mathrm{Cr}$.

made by Praveena \& Omar (2017), who reported total concentration of $\mathrm{Cr}, \mathrm{Cd}$, and $\mathrm{Pb}$ in rice was $2.7 \mathrm{mg} \mathrm{kg}^{-1}$, $0.16 \mathrm{mg} \mathrm{kg}^{-1,}$ and $0.11 \mathrm{mg} \mathrm{kg}^{-1}$ respectively, on the other hand, the mean of bioaccessible heavy metal concentrations were decreased to $0.11 \mathrm{mg} \mathrm{kg}^{-1}, 0.027 \mathrm{mg} \mathrm{kg}^{-1}$ and $0.022 \mathrm{mg} \mathrm{kg}^{-1}$, respectively. The long upper whisker in bioaccessible $\mathrm{Pb}$ denoted that bioaccessible fractions are varied higher among the greater values and very similar for lower values.

The bioaccessible Ni content was between 0.01 to $0.08 \mathrm{mg} \mathrm{kg}^{-1}$ with the median of $0.02 \mathrm{mg} \mathrm{kg}^{-1}$ and the bioccessible percentage ranged from 1.12 to 38.46 . So far no studies on the bioaccessibility of $\mathrm{Ni}$ were reported in rice. Bioaccessible $\mathrm{Cd}$ ranged from 0.01 to $0.09 \mathrm{mg} \mathrm{kg}^{-1}$ with the median of $0.035 \mathrm{mg} \mathrm{kg}^{-1}$ and the percent of bioaccessibility was between 2.33 to 42.86 . Omar et al. (2015) reported bioavailable $\mathrm{Cd}$ concentration was the lowest as compared to other metals in all cooked rice samples. Cadmium can be easily released from plants during the gastric phase of in vitro digestion process due to the presence of the pepsin enzyme and low $\mathrm{pH}$ (Zhuang et al., 2016). Also, pancreatic and bile extracts might precipitate most of the soluble $\mathrm{Cd}$ may be the result in decreased bioaccessible $\mathrm{Cd}$. Bioaccessible $\mathrm{Cr}$ ranged between 0.01 to 0.10 $\mathrm{mg} \mathrm{kg}{ }^{-1}$ with the median of $0.055 \mathrm{mg} \mathrm{kg}^{-1}$ and the percent of bioaccessibility was 1.02 to 45.45 . The box plot of bioaccessible $\mathrm{Cr}$ indicating that data sets are symmetric or normal distribution while bioaccessible $\mathrm{Pb}, \mathrm{Ni}$, and $\mathrm{Cd}$ are skewed towards the right indicating that the distribution is positively skewed. There are outliers only in bioaccessible $\mathrm{Pb}$ and $\mathrm{Ni}$ (Figure 2).

Invariably all the chosen metals showed a reduction in the bioaccessible fraction of heavy metal compared to total metals in the polished rice. Praveena \& Omar (2017) also reported the same and this may be due to the process adopted while cooking, digestion process, $\mathrm{pH}$ of the simulated condition, enzymes, etc.

\subsection{Correlation}

Correlation analysis was done to understand the relationship between metals in the polished rice and bioaccessible fraction (Figure 3). The present study reveals a significantly negative correlation which was observed among total heavy metals concentration and bioaccessibility in rice. Among the tested metals, Nickel and Chromium showed moderate negative correlation with bioaccessibility percentage (Figure 3b,d; $r=-$ $0.669 * * *$ and $r=-0.668 * * *)$. A significant weak negative correlation between lead and its bioaccessibility was noticed (Figure 3a; $r=-0.479 *$ ) whereas cadmium showed no significant weak negative correlation (Figure 3c). The present study revealed that the bioaccessibility of the analysed metals were independent of their total content. The observed variation in metal concentrations for analyzed foodstuffs might be due to variable capabilities of absorption and accumulation of metals by the crops (Kumari \& Kalpana 2017). 

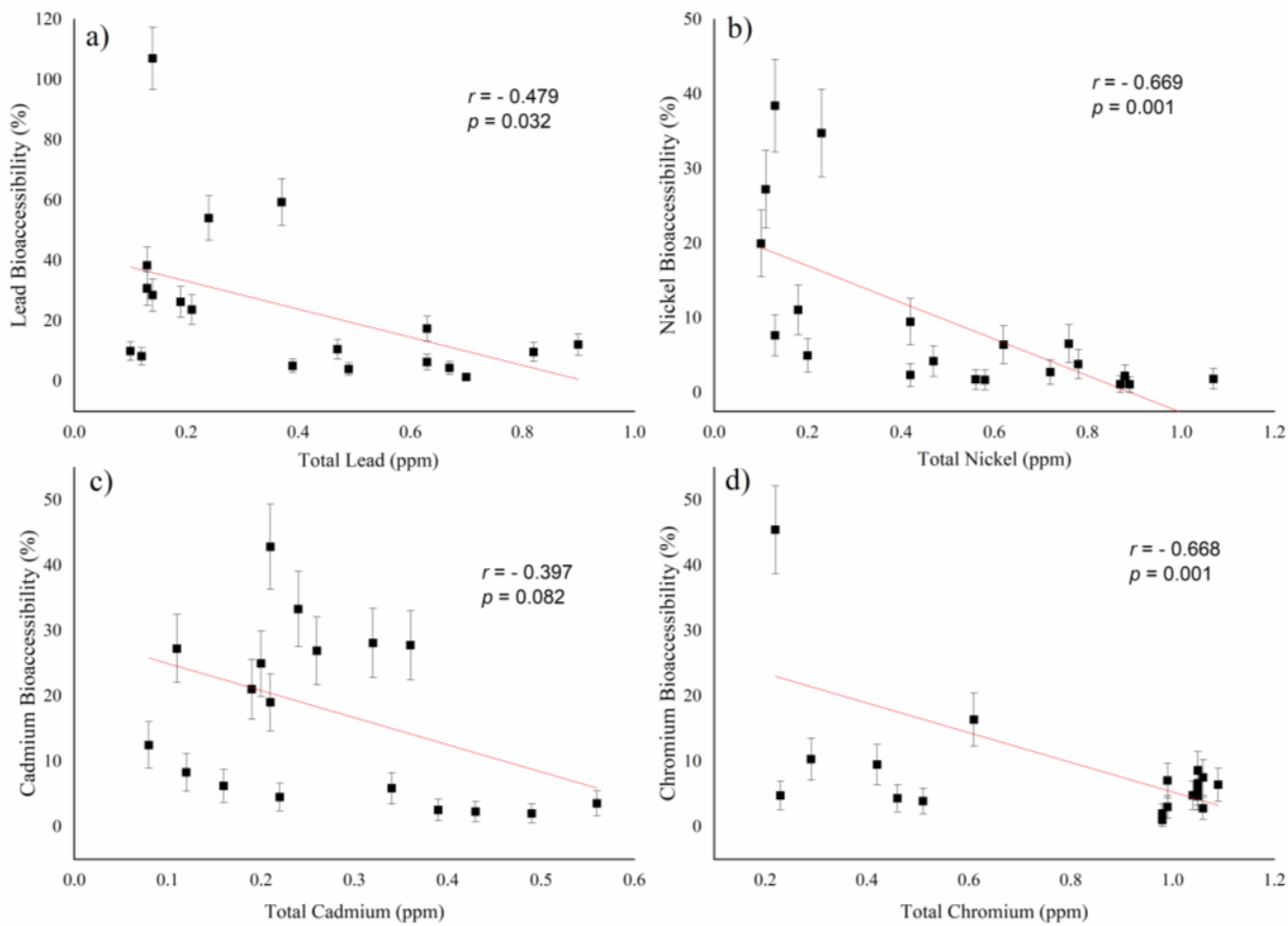

Figure 3 The correlation between total heavy metals concentration and bioaccessibility percentage in rice

\subsection{Target hazard quotient (THQ)}

Hazard quotient is an index of risk associated with long term exposure to a pollutant. It is the ratio of the potential exposure to a pollutant and the level at which no adverse effects are expected (USEPA, 2011). In the present study, few samples exceeded the total metal concentration above the permissible limit, however, THQ values were less than 1 indicating non-carcinogenic health risks (Figure 4). The target hazard quotient ranged from 1.18 to $8.83 \times 10^{-4}$ for lead, 1.1 to $92.2 \times 10^{-4}$ for nickel, 0.10 to $9.42 \times 10^{-4}$ for cadmium, and 1.73 to $8.56 \times 10^{-4}$ for chromium.

Many scientists have reported varying levels of THQ for different metals (Singh et al., 2014; Praveena \& Omar 2017). Similarly, Chandorkar \& Deota (2013) reported the THQ for Cd was 15 and Pd 78.6. Also, Singh et al. (2014) reported THQ of Cd (5.93 x 10 $\left.{ }^{3}\right), \mathrm{Pb}\left(2.17 \times 10^{-3}\right), \mathrm{Cr}\left(2.5 \times 10^{-4}\right)$ were showed no evidence of health risk.

\subsection{Principle component analysis (PCA)}

The Principle component analysis plot explained $49.10 \%$ of the variation pattern. The total metal concentration and total hazard quotient of $\mathrm{Cd}$ and $\mathrm{Cr}$ (Cd_T, Cr_T Cd_THQ, and Cr_THQ) and $\mathrm{Ni}$ bioaccessibility percentage (Ni-BAP) were major contributors to $\mathrm{PC} 1$. Whereas, $\mathrm{Pb}$ bioaccessible fraction (Ni-BF) was a major contributor to $\mathrm{PC} 2$. The two factors were well separated the $\mathrm{Cr}$ and Cd contaminated sampling locations in one group (green ellipse) and another group (pink ellipse) with $\mathrm{Ni}$ and $\mathrm{Pd}$ contaminated sampling locations. Based on studied variables, the sampling locations lies in positive quadrates of PC1 and PC2 denoted the high health risk while samples positioned in negative quadrates were associated with a low level of health risk. The rice sampling locations scattered in low health risk quadrants were mostly originated from Gobichettipalayam and in high health risk quadrants were obtained from Thanjavur, Villupuram, and Thiruvannamalai (Figure 5).

\subsection{Source of contamination}

This study has opened a wide scope for assessing the actual health risk in rice by using in vitro digestion model. Even though the origin of the samples were identified by the label, it may not be possible to conclude the source of heavy metals contamination. Further, there are few reasons by which the metals would have reached the rice grains. There may be few reasons by which metal would have reached the rice grains via cultivated soil, irrigation water, processing, handling, and cooking. There are evidences that the crops cultivated in heavy 
metal contaminated soils showed the highest accumulation than those cultivated in uncontaminated soils (Arao et al., 2010; Boyd, 2010; Zhang et al.. 2013).

To figure out the reasons associated with the presence of metal residues, a systematic investigation was carried out in the contaminated site. The site chosen for the study was a tannery contaminated site at Vellore, Tamil Nadu. The delineated 'hotspots' of chromium contamination in the Vellore district identified by our previous workers (Sunitha et al., 2015) where six taluks (Walajahpet, Arcot, Vellore, Tirupathur, Vaniyambadi, and Gudiyatham) were selected for present study. From each spot, four rice growing farmers field were identified for sample collection (soil, water and rice grain).
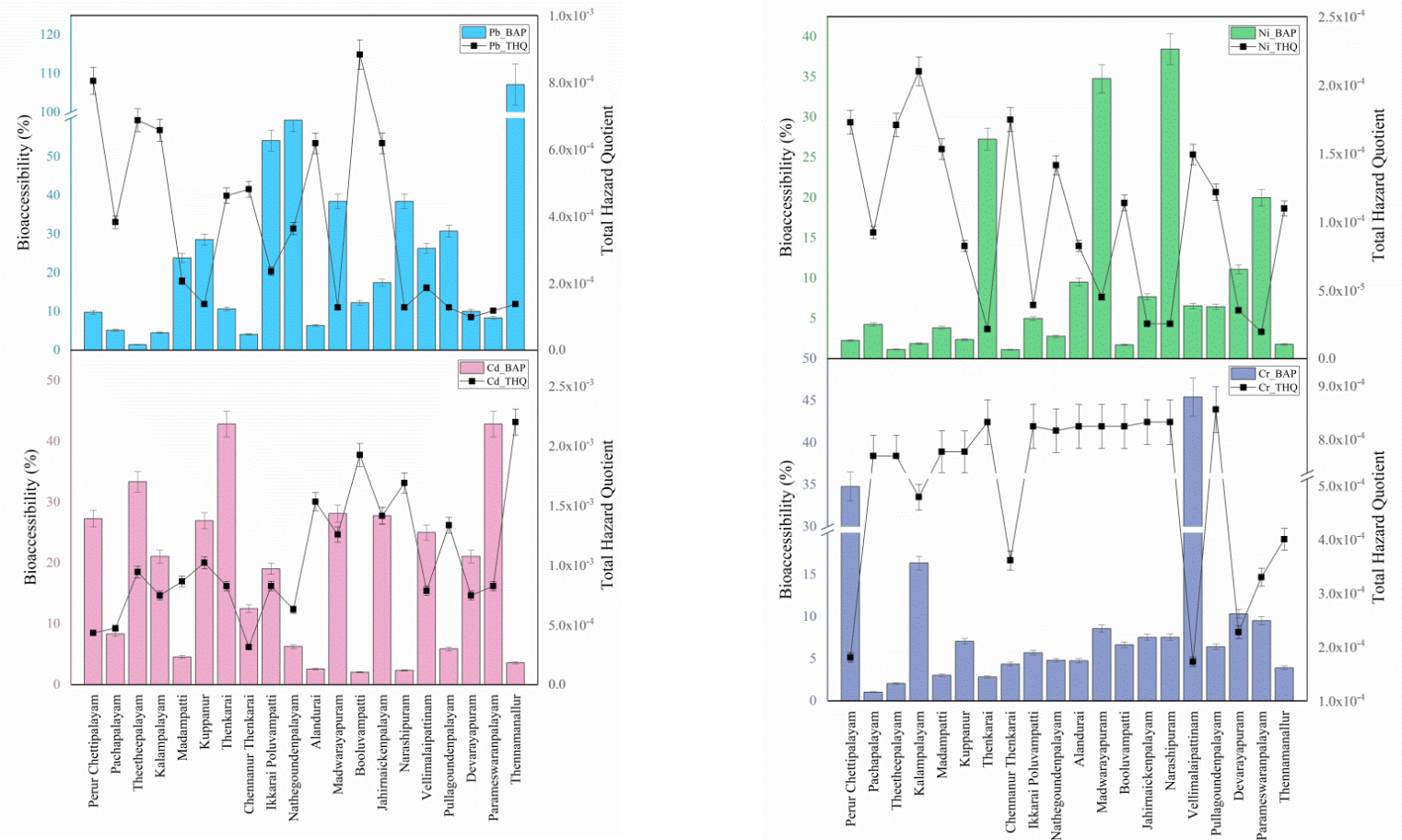

Figure 4 The bioaccessibility percentage and target hazard quotient of in rice samples collected from various locations
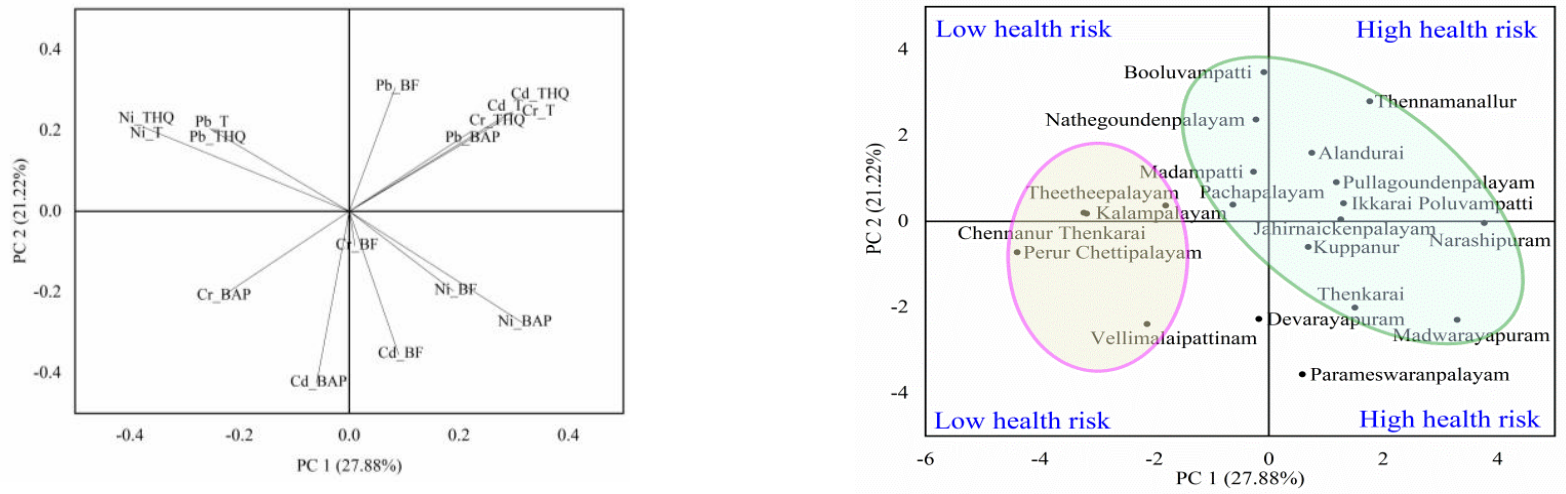

Figure 5 Biplot of PC1 and PC2 for heavy metal contaminated rice collected from various location (Where T is total metal concentration, $\mathrm{BF}$ is bioaccessible fraction, BAP is bioaccessibility percentage, THQ is total hazard quotient)

Journal of Experimental Biology and Agricultural Sciences http://www.jebas.org 


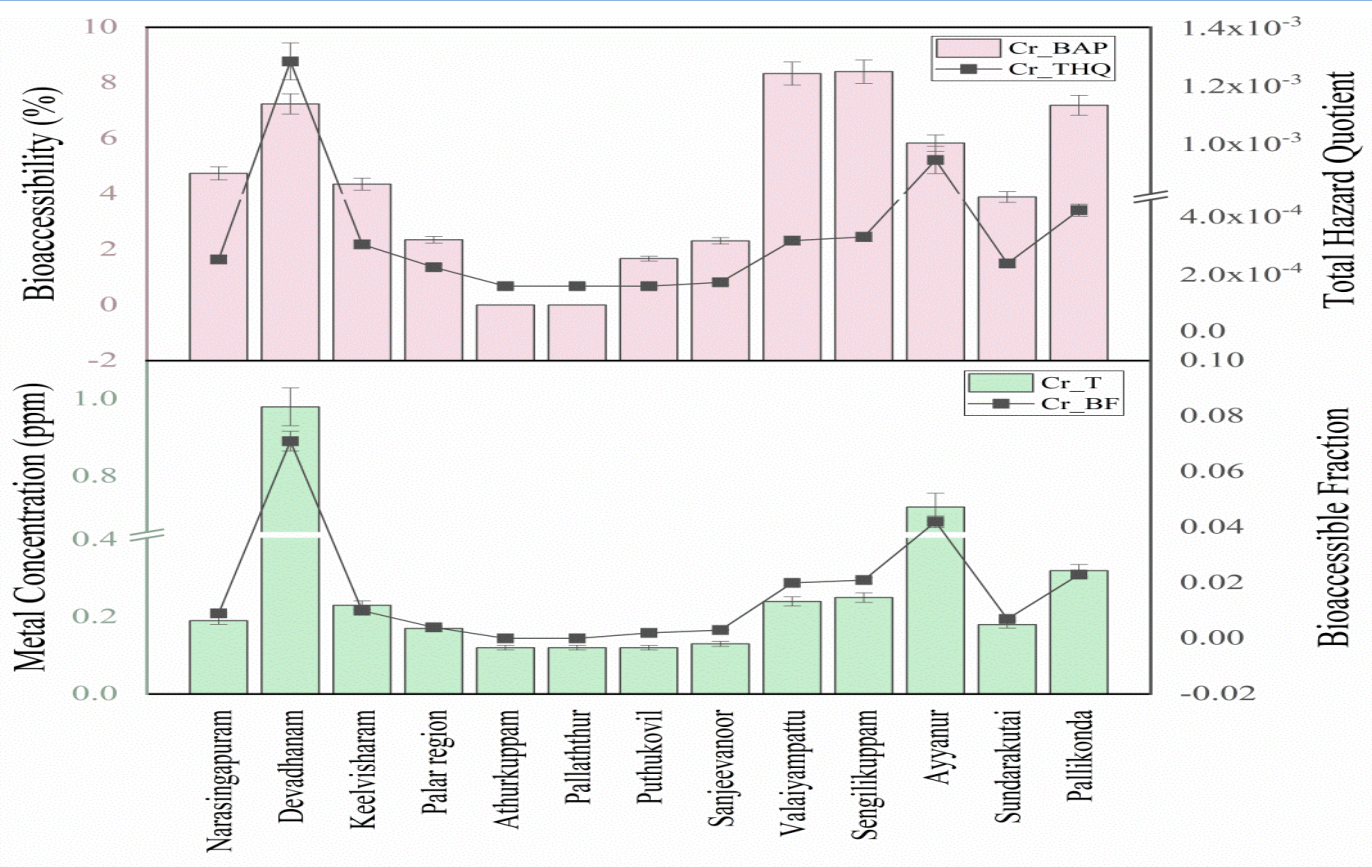

Figure 6 Chromium contamination in rice collected from various sites of Vellore district

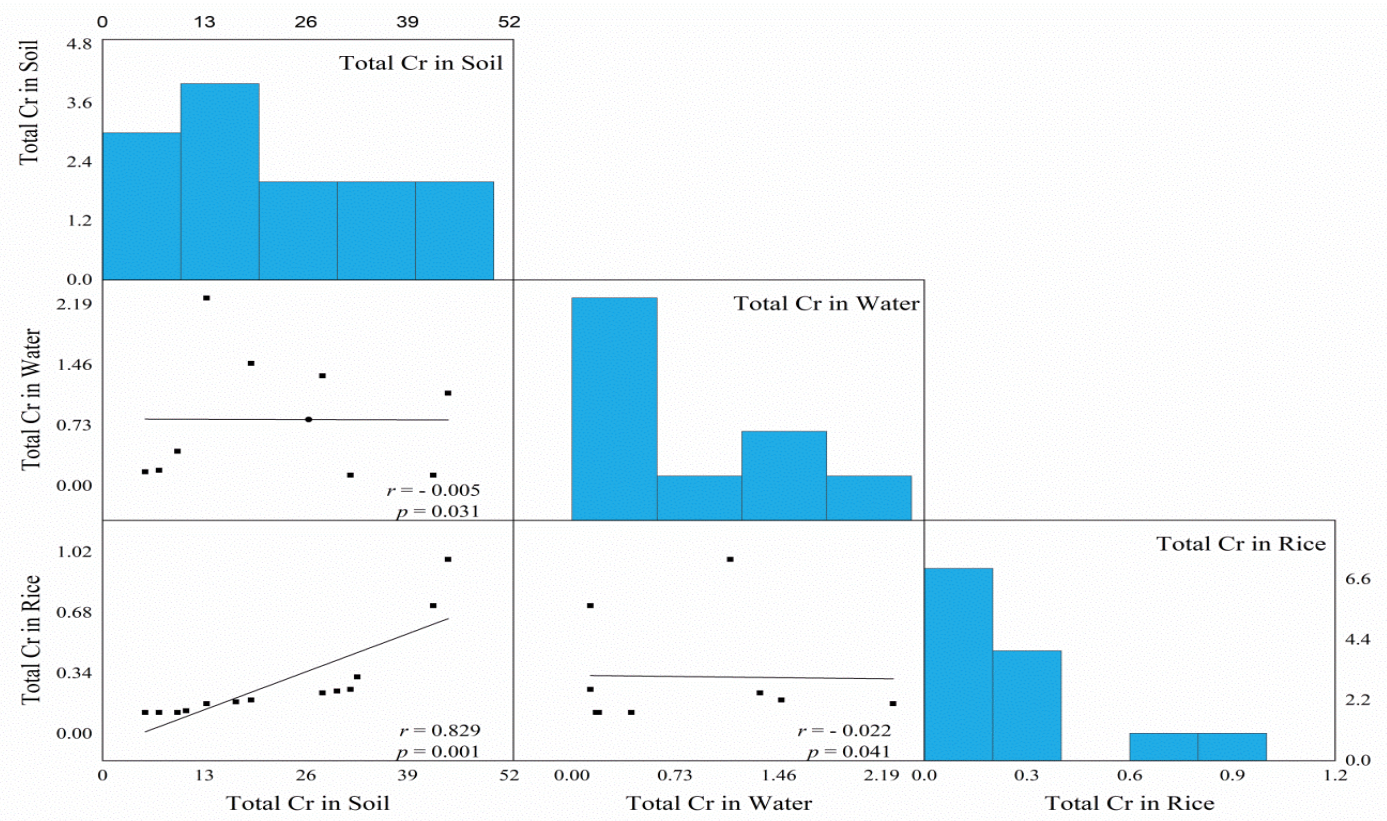

Figure 7 Scatter matrix of total chromium content in soil, water and rice grain.

The maximum chromium content in soil was registered in Devadhanam (44.16 mg kg-1) followed by Ayyanur (42.29 $\mathrm{mg} \quad \mathrm{kg}^{-1}$ ) and Pallikonda (32.57 $\mathrm{mg} \mathrm{kg}^{-1}$ ) while the minimum was recorded in Athurkuppam (5.45 mg kg-1). The chromium content in the water sample recorded maximum in Palar region $\left(2.27 \mathrm{mg} \mathrm{L}^{-1}\right)$ followed by Narasingapuram $\left(1.48 \mathrm{mg} \mathrm{L}^{-1}\right)$ and Keelvisharam $\left(1.33 \mathrm{mg} \mathrm{L}^{-1}\right)$ whereas samplings from Sanjeevanoor, Valaiyampattu, Sundarakutai, and Pallikonda were registered below the detectable limit. 


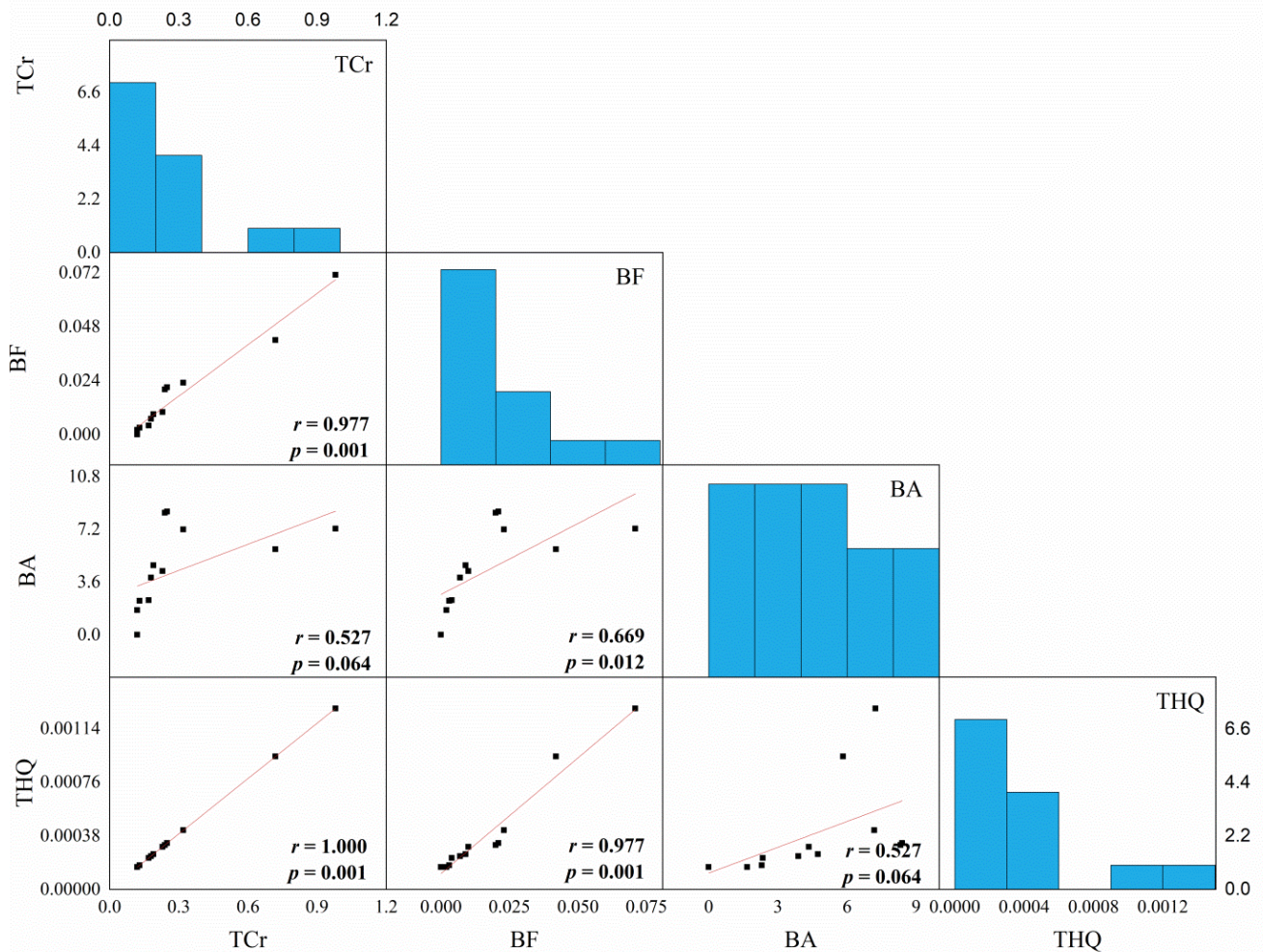

Figure 8 The correlation between metal bioaccessibility and target hazard quotient in rice

Total chromium content ranged from 0.12 to $0.98 \mathrm{mg} \mathrm{kg}^{-1}$ (Median $0.19 \mathrm{mg} \mathrm{kg}^{-1}$ ) for polished rice and 0 to $0.071 \mathrm{mg}$ $\mathrm{kg}^{-1}$ (Median $0.009 \mathrm{mg} \mathrm{kg}^{-1}$ ) for bio accessible fraction. The bioaccessible percentage varied from 0 to 8.40 (Median 4.35). Target hazard quotient ranged from 1.57 to $1.28 \times 10^{-3}$ (Median $2.49 \times 10^{-4}$ ). However, in present study chromium concentrations were well within the permissible limit to food grains $\left(1 \mathrm{mg} \mathrm{kg}^{-1}\right.$ ) (Figure 6).

A significant positive correlation between total chromium content in rice samples and soil total chromium was evident for biomagnifications of chromium from soil to rice grains. Furthermore, a significant positive correlation was observed between total chromium content and target hazard quotient and also with bioaccessible fractions in rice samples (Figure $7 \& 8$ ). High chromium in the soil is directly correlated with the total chromium in rice even though it is below the tolerable level.

\section{Conclusion}

The study showed that the total and bioaccessible heavy metals were higher than the maximum permissible limits in few polished rice samples. Consumption of foodstuff with elevated levels of heavy metals for the long term may lead to health disorders. Therefore regular monitoring of heavy metals is essential to reduce the intensive accumulation of heavy metals in the human food chain. Because of the paucity of data on bioaccessible heavy metals in rice, no comparison with heavy metals by other researchers can be drawn. However, the present study confirms that bioaccessible metals were independent of total content and soil-water contaminated environment may be the reasons for the entry of heavy metals in rice grains.

\section{Acknowledgements}

Authors are thankful to Agricultural College and Research Institute, Tamil Nadu Agricultural University, Coimbatore for operating this research as University Research Project and the authors are also would like to thank Dr. K. Valliappan and Dr. M. Sudhakaran for their valuable support and suggestions.

\section{Declaration of interests}

The authors declare that they have no known competing financial interests or personal relationships that could have appeared to influence the work reported in this paper. 


\section{References}

Abbas A, Murtaza S, Aslam F, Khawar A, Rafique S, Naheed S (2011) Effect of processing on nutritional value of rice (Oryza sativa). World Journal of Medical Sciences 6(2): 68-73.

Arao T, Ishikawa S, Murakami M, Abe K, Maejima Y, Makino T (2010) Heavy metal contamination of agricultural soil and countermeasures in Japan. Paddy and water Environment 8(3): 247-257.

Bhattacharya P, Samal AC, Majumdar J, Santra SC (2010) Accumulation of arsenic and its distribution in rice plant (Oryza sativa L.) in Gangetic West Bengal, India. Paddy and Water Environment 8(1): 63-70.

Boyd RS (2010) Heavy metal pollutants and chemical ecology: exploring new frontiers. Journal of Chemical Ecology 36(1): 4658.

Cao Z, Mou R, Cao Z, Lin X, Xu P, Chen Z, Chen M (2017) Nickel in milled rice (Oryza sativa L.) from the three main riceproducing regions in China. Food Additives \& Contaminants: Part B 10(1): 69-77.

Chandorkar S, Deota P (2013) Heavy metal content of foods and health risk assessment in the study population of Vadodara. Current world environment 8(2): 291.

Chaoua S, Boussaa S, El Gharmali A, Boumezzough A (2019) Impact of irrigation with wastewater on accumulation of heavy metals in soil and crops in the region of Marrakech in Morocco. Journal of the Saudi Society of Agricultural Sciences 18(4): 429-436.

Dang HS, Jaiswal DD, Parameswaran M, Deodhar KP, Krishnamony S (1996) Age dependent physical and anatomical Indian data for application in internal dosimetry. Radiation Protection Dosimetry 63(3): 217-222.

Devesa V, Velez D, Montoro R (2008) Effect of thermal treatments on arsenic species contents in food. Food and Chemical Toxicology 46(1): 1-8.

Etikan I, Musa SA, Alkassim, RS (2016) Comparison of convenience sampling and purposive sampling. American journal of theoretical and applied statistics 5(1): 1-4.

Ghuniem MM, Khorshed MA, Khalil MM (2020) Determination of some essential and toxic elements composition of commercial infant formula in the Egyptian market and their contribution to dietary intake of infants. International Journal of Environmental Analytical Chemistry 100(5):525-48.
Hang X, Wang H, Zhou J, Ma C, Du C, Chen X (2009) Risk assessment of potentially toxic element pollution in soils and rice (Oryza sativa) in a typical area of the Yangtze River Delta. Environmental pollution 157(8-9): 2542-2549.

Huang CL, Bao LJ, Luo P, Wang ZY, Li SM, Zeng EY (2016) Potential health risk for residents around a typical e-waste recycling zone via inhalation of size-fractionated particle-bound heavy metals. Journal of hazardous materials 317: 449-456.

Ihedioha JN, Ujam OT, Nwuche CO, Ekere NR, Chime CC (2016) Assessment of heavy metal contamination of rice grains (Oryza sativa) and soil from Ada field, Enugu, Nigeria: Estimating the human health risk. Human and Ecological Risk Assessment: An International Journal 22(8): 1665-1677.

Intawongse M, Dean JR (2008) Use of the physiologically-based extraction test to assess the oral bioaccessibility of metals in vegetable plants grown in contaminated soil. Environmental Pollution 152(1): 60-72.

Jorhem L, Åstrand C, Sundström B, Baxter M, Stokes P, Lewis J, Grawe KP (2008) Elements in rice from the Swedish market: 1. Cadmium, lead and arsenic (total and inorganic). Food Additives and Contaminants 25(3): 284-292.

Juhasz AL, Smith E, Weber J, Rees M, Rofe A, Kuchel T, Naidu $\mathrm{R}$ (2006) In vivo assessment of arsenic bioavailability in rice and its significance for human health risk assessment. Environmental Health Perspectives 114(12): 1826-1831.

Khairiah J, Azie RR, Habibah J, Zulkifle I, Ismail BS (2013) Heavy metal content of paddy plants in Langkawi, Kedah, Malaysia. Australian Journal of Basic and Applied Sciences 7(2): 123-127.

Khanam R, Kumar A, Nayak AK, Shahid M, Tripathi R, Vijayakumar S, Bhaduri D, Kumar U, Mohanty S, Panneerselvam P, Chatterjee D (2020) Metal (loid) s (As, Hg, Se, Pb and Cd) in paddy soil: Bioavailability and potential risk to human health. Science of the Total Environment 699:134330.

Kumari M, Kalpana P (2017) Bioaccessibility of trace elements and chromium speciation in commonly consumed cereals and pulses. International Journal of Food Properties 20(7): 1612-1620.

Morekian R, Mirlohi M, Azadbakht L, Maracy MR (2013) Heavy metal distribution frequency in Iranian and imported rice varieties marketed in central Iran, Yazd, 2012. International journal of environmental health engineering 2(1): 36-40

Naseri M, Rahmanikhah Z, Beiygloo V, Ranjbar S (2018) Effects of two cooking methods on the concentrations of some heavy 
metals (cadmium, lead, chromium, nickel and cobalt) in some rice brands available in Iranian Market. Journal of chemical health risks 4(2): 65-72.

Omar NA, Praveena SM, Aris AZ, Hashim Z (2015) Bioavailability of heavy metal in cooked rice and health risk assessment using in vitro digestion model. International Journal of Basic Science and Applied Research 19: 358-367.

Praveena SM, Omar NA (2017) Heavy metal exposure from cooked rice grain ingestion and its potential health risks to humans from total and bioavailable forms analysis. Food chemistry 235 203-211.

Rai PK, Tripathi BD (2008) Heavy metals in industrial wastewater, soil and vegetables in Lohta village, India. Toxicological and Environ Chemistry 90(2): 247-257.

Ray DK, West PC, Clark M, Gerber JS, Prishchepov AV, Chatterjee S (2019) Climate change has likely already affected global food production. PloS one 14(5):217148.

Ruby MV, Davis A, Schoof R, Eberle S, Sellstone CM (1996) Estimation of lead and arsenic bioavailability using a physiologically based extraction test. Environmental Science \& Technology 30(2): 422-430.

Sandberg AS (2005) Methods and options for in vitro dialyzability benefits and limitations. International Journal for Vitamin and Nutrition Research 75(6) 395-404.

Satpathy D, Reddy, MV, Dhal SP (2014) Risk assessment of heavy metals contamination in paddy soil, plants, and grains (Oryza sativa L.) at the East Coast of India. BioMed Research International 2014:1-11

Sen Gupta S, Baksi A, Subramanian V, Pradeep T (2016) Cooking-induced corrosion of metals. ACS Sustainable Chemistry \& Engineering 4(9): 4781-4787.

Singh J, Upadhyay SK, Pathak RK, Gupta V (2011) Accumulation of heavy metals in soil and paddy crop (Oryza sativa), irrigated with water of Ramgarh Lake, Gorakhpur, UP, India. Toxicological \& Environmental Chemistry 93(3): 462-473.

Singh M, Garg VK, Gautam YP, Kumar A (2014) Soil to grain transfer factors of heavy metals in rice and health risk analysis in the vicinity of Narora Atomic Power Station (NAPS), Narora, India India. Journal of Science Industrial Research 73:181-86.

Solidum J, Dykimching E, Agaceta C (2012) Assessment and Identification of heavy metals in different types of cooked rice available in the Philippine market. 2nd International Conference on Environmental and Agriculture Engineering 37:35-9.
Sun GX, Van de Wiele T, Alava P, Tack F, Du Laing G (2012) Arsenic in cooked rice: effect of chemical, enzymatic and microbial processes on bioaccessibility and speciation in the human gastrointestinal tract. Environmental Pollution 162:241-6.

Sunitha R, Purushothaman G, Alagirisamy B, Santiago M (2015) Chromium contamination in soil and groundwater due to tannery wastes disposals at Vellore district of Tamil Nadu. International Journal of Environmental Sciences 6(1): 114-124.

United States Environmental Protection Agency (US EPA) (2007) Integrated risk information system (IRIS). Database Phidelphia PA. Washington DC, USA.

United States Environmental Protection Agency (US EPA) (2011) Exposure Factors Handbook 2011 Edition (Final); Office of Emergency and Remedial Response: Washington, DC, USA.

United States Environmental Protection Agency (US EPA) (2020) Integrated risk information system (IRIS). https://cfpub.epa.gov/ncea/iris/search/index.cfm?first_letter=C (accessed August 16, 2020).

USEPA (US Environmental Protection Agency). (1997). Exposure factors handbook. EPA/600/P-95/002Fa-c. vol. I. Office of Research and Development. National Center for Environmental Assessment.US Environmental Protection Agency, Washington, DC, USA.

Versantvoort CH, Oomen AG, Van de Kamp E, Rompelberg CJ, Sips AJ (2005) Applicability of an in vitro digestion model in assessing the bioaccessibility of mycotoxins from food. Food and Chemical Toxicology 43(1): 31-40.

WHO Joint FAO, Expert Committee on Food Additives, World Health Organization. (2004) Evaluation of certain food additives and contaminants: sixty-first report of the Joint FAO/WHO Expert Committee on Food Additives. World Health Organization.

Yang LS, Zhang XW, Li YH, Li HR, Wang Y, Wang WY (2012) Bioaccessibility and risk assessment of cadmium from uncooked rice using an in vitro digestion model. Biological trace element research 145(1): 81-86.

Zhang X, Wang H, He L, Lu K, Sarmah A, Li J, Huang H (2013) Using biochar for remediation of soils contaminated with heavy metals and organic pollutants. Environmental Science and Pollution Research 20(12): 8472-8483.

Zhuang P, Zhang C, Li Y, Zou B, Mo H, Wu K, Li Z (2016) Assessment of influences of cooking on cadmium and arsenic bioaccessibility in rice, using an in vitro physiologically-based extraction test. Food chemistry 213: 206-214. 